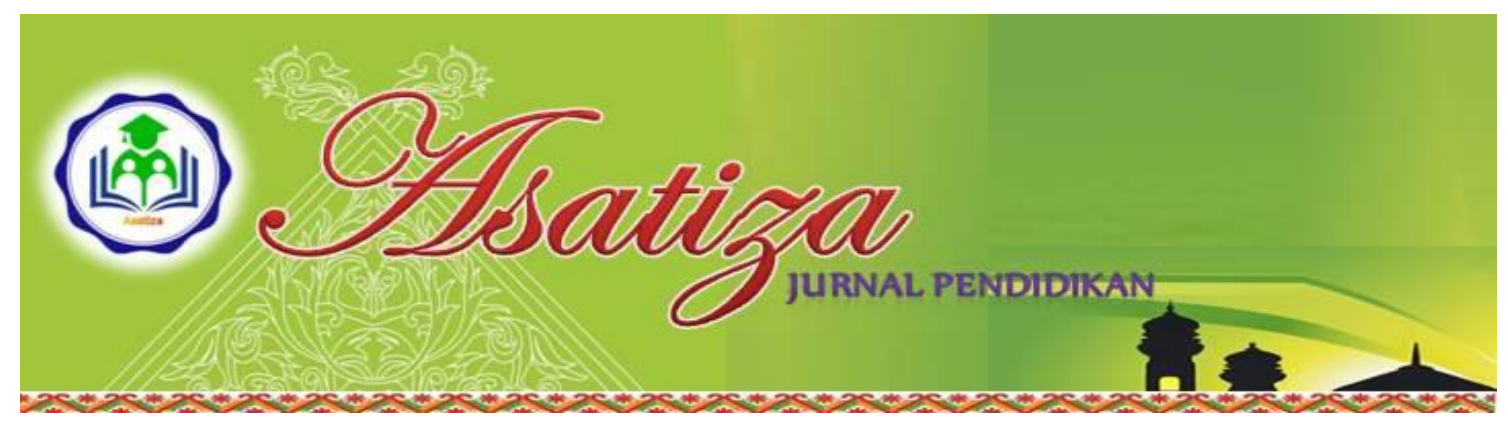

\title{
PENGARUH PENGETAHUAN PENDIDIKAN KARAKTER TERHADAP ETIKET SISWA DI MADRASAH IBTIDAIYAH NURUL HUDA PARIT 5 SUNGAI LUAR KECAMATAN BATANG TUAKA
}

\begin{abstract}
$\operatorname{Irfan}^{1}$
${ }^{1}$ STAI Auliaurrasyidin Tembilahan

Abstrak

Tujuan penelitian ini adalah untuk (1) Mengetahui pendidikan karakter siswa (2) Mengetahui Etiket siswa (3) Mengetahui Pengaruhpendidikan karakter terhadap Etiket siswa. Jenis penelitian ini adalah penelitian Regresi. Penelitian Regresi untuk melihat ada tidaknya pengaruh antar satu variabel dengan variabel yang lainnya. Populasi dalam penelitian ini adalah 33 orang siswa kelas IV dan V. Sampel diambil sebanyak 33orang dengan menggunakan sampel jenuh. Data dalam penelitian ini dikumpulkan dengan menggunakan teknik angket dan dokumentasi. Selanjutnya data yang terkumpul dianalisa dengan menggunakan rumus Regresi Sederhana.

Hasil analisa data angket dapat disimpulkan bahwa: (1) Pendidikan karakter siswa dengan kategori "cukup baik" dan persentase akhir 60,37\%. (2) Etiket siswa dengan kategori "cukup baik" dan persentase akhir 60,75\%. (3) Ada pengaruh signifikanantara Pengetahuann Pendidikan karakter terhadap Etiket siswa dengan $\mathrm{F}$ hitung $=71,78 \geq$ Ftabel $=4,17$.
\end{abstract}

Kata Kunci: Pengetahuan, Pendidikan Karakter, Etiket

\section{A. PENDAHULUAN}

\section{Latar belakang}

Tujuan pendidikan nasional yang tertuang dalam UU. No. 20 tahun 2003 pasal 3 yaitu:

Pendidikan nasional berfungsi mengembangakan kemampuan dan membentuk watak serta peradaban bangsa yang bermanfaat dalam rangka mencerdaskan kehidupan bangsa, bertujuan untuk berkembangnya potensi peserta didik agar menjadi manusia yang beriman dan berwatak kepada
Tuhan Yang Maha Esa, berakhlak mulia, sehat, berilmu, cakap, kreatif, mandiri dan menjadi warga Negara yang demokratis serta tanggung jawab. ${ }^{1}$

Jalur pendidikan adalah wahana yang dilalui peserta didik untuk mengembangkan potensi diri dalam suatu proses pendidikan yang sesuai dengan tujuan pendidikan. Dalam UU No. 20 Tahun 2003 Pasal 13 ayat 1 dinyatakan bahwa jalur pendidikan

${ }^{1}$ Undang-undang Sistem Pendidikan Nasional. (Yogyakarta: Pustaka Pelajar, 2006), hal. 8 
terdiri dari pendidikan formal, non formal, dan informal.

Fenomena rusaknya karakter akan semakin cepat ketika masyarakat pengguna teknologi tidak memahami filosofi teknologi sehingga salah dalam memanfaatkan dan memandang nilai fungsi teknologi. Bagi banyak siswa, nilai teknologi telah bergeser, dari alat untuk memudahkan dan membuat kenyamanaan hidup menjadi bagian dari prasyarat pergaulan dan simbolsimbol kelas sosial. Pendidikan karakter yang kita laksanakan memang tidak serta merta akan menampakkan bentuk atau hasil, tetapi merupakan proses panjang. namun, pelaksanaan pendidikan karakter di negara ini dapat menjadi pemicu agar kita segera melaksanakan pendidikan karakter ini. ${ }^{2}$ Bagi pendidik, pendidikan karakter membantu pendidik dalam memenuhi tanggung jawab fundamental mereka, yakni mempersiapkan masa depan anak-anak dengan meningkatkan kepedulian, hormat, dan iklim berprestasi di sekolah.

Memahami sejarah sebuah konsep sungguh sangat penting untuk dapat memahami dalam konteks apa konsep itu lahir, dan untuk apa konsep itu. diperjuangkan. Merujuk pada pendapat para tokoh, pemimpin dan pakar pendidikan dunia yang menyepakati pembentukan karakter sebagai tujuan pendidikan, maka sejarah pendidikan karakter sama tuanya dengan itu sendiri.

${ }^{2}$ Barnawi, M. Arifin, Stratrgi dan Kebijakan Pembelajaran Pendidikan Karakter. (Yogyakarta: Ar-Ruzz Media, 2016), hal. 17

${ }^{3}$ Abdul Majid, Dian Andayani, Pendidikan Karakter Perspektif Islam. (Bandung: PT Remaja Rosdakarya, 2011), hal. 2
Namun dalam perjalanannya, pendidikan karakter sempat tenggelam dan terlupakan dari dunia pendidikan, terutama sekolah. $^{3}$

Pendidikan karakter merupakan sebuah upaya untuk membimbing perilaku manusia menuju standarstandar baku. Dalam hal ini karakter dapat ditemukan dalam sikap-sikap seseorang terhadap dirinya, terhadap orang lain, terhadap tugas-tugas yang dipercayakan padanya dan dalam situasi-situasi yang lainnya. Dengan demikian karakter dan akhlak tidak memiliki perbedaan yang signifikan. ${ }^{4}$

Pendidikan di sekolah seharusnya memang bukan sekedar memberikan berbagai macam pengetahuan, melainkan pula harus bisa membentuk karakter siswanya. Aspek ini penting untuk direnungkan bersama karena realitas selama ini menunjukkan bahwa pembentukkan karakter memang kurang mendapatkan apresiasi dan perhatian memadai. Konsentrasi guru lebih pada bagaimana siswa mendapatkan nilai yang memuaskan secara akademis.

Tujuan utama pendidikan adalah menyiapkan anak didik yang berintelektual dan bermoral tinggi. Jadi, sekolah tidak hanya mendidik anak agar menjadi orang pandai, tetapi juga bermoral. Itulah idealitas yang seyogianya menjadi perhatian semua pihak yang memiliki kepedulian dalam dunia pendidikan. ${ }^{5}$

\footnotetext{
${ }^{4}$ Abdul Majid, Dian Andayani, Pendidikan Karakter Perspektif Islam. (Bandung: PT Remaja Rosdakarya, 2011), hal. 11-12

${ }^{5}$ Ngainun Naim, Character Building: Optimalisasi Peran Pendidikan dalam
} 
Gagasan untukmemperkuat pendidikan karakter di sekolah-sekolah pun mendapat sambutan, tanggapan, dan apresiasi secara luas. Banyak pihak yang melihat bahwa gagasan tersebut harus segera diterjemahkan dalam tataran praktis. Sebab jika hanya berhenti pada tataran wacana, tidak akan banyak perubahan yang terjadi. Sementara di sisi lain, kebobrokan dan kemerosotan terus berlangsung secara massif.

Setiap orang tua mengharapkan anaknya untuk bisa mendapatkan pendidikan Islam. Dengan pendidikan Islam kita berusaha untuk membentuk manusia yang berkepribadian kuat dan baik berdasarkan pada ajaran agama Islam.

Dalam hal ini, peneliti menemukan beberapa masalah yang berkaitan dengan karakter dan etiket didalam diri siswa di Madrasah Ibtidaiyah Nurul Huda Parit 5 ini yang dijadikan alasan sebagai pertimbangan untuk melakukan penelitian:

a. Sering menggunakan bahasa yang tidak santun.

b. Acuh terhadap perintah dan nasehat guru.

c. Kurangnya kemandirian dalam mengerjakan tugas.

d. Kurangnya kesadaran bergotong royong.

e. Sering terjadi keributan saat jam belajar.

Pengembangan Ilmu \& Pembentukkan Karakter Bangsa. (Jogjakarta: Ar-Ruzz Media, 2012), hal.40

${ }^{6}$ Ngainun Naim, Character Buliding: Optimalisasi Peran Pendidikan dalam Pembangunan Ilmu dan Pembentukkan Karakter
Dalam penelitian ini, peneliti mengambil beberapa nilai karakter dari 18(delapan belas) nilai karakter yang harus dimiliki setiap individu siswasiswi. Nilai-nilai pembangun karakter tersebut antara lain; religius, jujur, toleransi, disiplin, kerja keras, kreatif, mandiri, demokratis, rasa ingin tahu, semangat, kebangsaan, cinta tanah air, menghargai prestasi, bersahabat, cinta damai, gemar membaca, pantang menyerah, peduli lingkungan, dan peduli sesama. ${ }^{6}$ Dimana karakterkarakter tersebut akan memperngaruhi perilaku siswa yang diantaranya perilaku religius, jujur, toleransi, dan peduli sesama. Berdasarkan latar belakang masalah yang telah dipaparkan diatas, maka rumusanrumusan masalah dalam penelitian ini adalah: Bagaimana pendidikan Karakter siswa di Madrasah Ibtidaiyah Nurul Huda parit 5 Sungai luar kecamatan batang tuaka ?, Bagaimana etiket siswa di Madrasah Ibtidaiyah Nurul Huda parit 5 sungai luar kecamatan batang tuaka ?, Apakah ada pengaruh pengetahuan pendidikan Karakter terhadap etiket siswa di Madrasah Ibtidaiyah Nurul Huda parit 5 sungai luar kecamatan batang tuaka?

\section{Pengertian Karakter}

Secara etimologi, kata karakter berasal dari bahasa Inggris(character) dan Yunani (character) yang berarti membuat tajam, membuat dalam. ${ }^{7}$

Bangsa. (Jogjakarta: Ar-Ruzz Media, 2012), hal.123-207

${ }^{7}$ Lorens Bagus, Kamus Filsafat. (Jakarta: Gramedia, 2000), hal. 392 
Menurut Kamus Besar Bahasa Indonesia karakter diartikan sebagai sifat-sifat kejiwaan, etika atau budi pekerti yang membedakan individu dengan yang lain. Karakter bisa diartikan tabiat, perangai atau perbuatan yang selalu dilakukan (kebiasaan). Karakter juga diartikan watak atau sifat batin manusia yang mempengaruhi segenap pikiran dan tingkah laku. ${ }^{8}$

Secara terminologi, karakter diartikan sebagai sifat manusia pada umumnya yang bergantung pada factor kehidupannya sendiri. ${ }^{9}$ M. Furqon Hidayatullah mengutip dari Rutland mengemukakan bahwa kata karakter berasal dari bahasa Latin yang berarti dipahat. Sebuah kehidupan, seperti sebuah blok granit dengan hati-hati memahatnya. Ketika dipukul sembarangan, maka akan rusak. Karakter merupakan gabungan dari kebijakan dan nilai-nilai yang dipahat dalam batu hidup tersebut, sehingga akan menyatakan nilai yang sebenarnya. ${ }^{10}$

Karakter secara lebih jelas mengacu kepada serangkaian sikap (attitudes), perilaku (behaviours), motivasi (motivations), dan keterampilan (skills). Karakter meliputi sikap seperti keinginan untuk melakukan hal yang terbaik, kapasitas intelektual, seperti berfikir kritis dan alasan moral, perilaku seperti jujur dan bertanggungjawab mempertahankan prinsip-prinsip moral dalam situasi penuh ketidakadilan, kecakapan interpersonal dan emosional yang memungkinkan seseorang berinteraksi secara efektif dalam berbagai keadaan, dan komitmen untuk berkonstribusi dengan komunitas dan masyaraktnya. Dari kata karakter kemudian berkembangan positif sebagai individu (intelektual, sosial, emosional, dan etika). Individu yang berkarakter baik adalah seseorang yang berusaha melakukan hal yang terbaik. ${ }^{11}$

\section{Pendidikan Karakter di Indonesia}

Pendidikan karakter bukan hal baru di Indonesia. Tokoh-tokoh pendidik Indonesia pra kemerdekaan, seperti Kartini, Ki Hajar Dewantoro, Soekarno Hatta, Moh Natsir sudah memulai apa yang dinamakan pendidikan karakter sebagai semangat pembentukkan kepribadian dan identitas bangsa sesuai konteks dan situasi yang terjadi saat itu.

Membangun dan mencetak karakter bangsa merupakan keprihatinan pokok para tokoh tersebut. Mereka menggagas sebuah bangsa yang memiliki identitas tersendiri. Ide dan gagasan itu dimulai dari hasil pengembaraan dan perantauan mental para pemikir dan cendekiawan. ${ }^{12}$
${ }^{8}$ Poerwadarminta, Kamus Besar Bahasa Indonesia. (Jakarta: Balai Pustaka, 1997), hal.20

${ }^{9}$ Agus Zainul Fitri, Reinventing Human Character: Pendidikan Karakter Berbasis Nilai\& Etika di Sekolah. (Jogjakarta: Ar-Ruzz Media, 2012), hal. 2017

${ }^{10} \mathrm{M}$. Furqon Hidayatullah, Pendidikan Karakter: Membangun Peradaban Bangsa. (Surakarta: Yuma Pustaka, 2010), hal. 12

\footnotetext{
${ }^{11}$ Ngainun Naim, Character Building: Optimalisasi Peran Pendidikan dalam Pengembangan Ilmu \& Pembentukkan Karakter Bangsa. (Jogjakarta: Ar-Ruzz Media, 2012), hal.4956

${ }^{12}$ Alfian, Politik, Kekulturan dan Manusia Indonesia. (Jakarta: LP3S, 1980), hal. 51
} 
Dari ide dan gagasan itu, muncullah semangat karakter kebangsaan yang harus diperjuangkan dengan perjuangan tanpa akhir sehingga muncullah negara Indonesia saat ini.

Membangun karakter dan watak bangsa melalui pendidikan, mutlak dibutuhkan. Mulai diri sendiri, lingkungan rumah, sekolah dan masyarakat dengan meneladani para tokoh tersebut. Ratna Megawangi menilai bahwa pendidikan karakter dan etika di Indonesia saat ini kurang mendapat penekanan dalam sistem pendidikan negara. Pelajaran PKN, Agama budi pekerti sekarang selama ini dianggap tidak berhasil. Karena pelajarannya hanya sebatas teori, tanpa adanya refleksi dari nilai-nilai pendidikan tersebut. Dampaknya anak tumbuh menjadi manusia yang tidak memiliki karakter, bahkan dinilai lebih buruk lagi menjadi generasi yang tidak bermoral. ${ }^{13}$ Pemerintah Indonesia dekade awal kemerdekaan sudah mengupayakan adanya pendidikan karakter di sekolah. Hal ini ditegaskan dan dituangkan dalam UU Pendidikan Nasional, yaitu UU No. 4/1950 jo UU No. 12/1954, UU No. 2/1989 hingga UU No. 20/2003. ${ }^{14}$ Pemerintah melalui undang-undang tersebut berupaya agar pendidikan karakter diterapkan secara optimal pada lembaga pendidikan. Namun karakter yang terbentuk justru bertentangan dengan tujuan pendidikan. Dengan demikian diperlukan

${ }^{13}$ Ratna Megawangi, Pendidikan Karakter Solusi yang Tepat untuk Membangun Bangsa. (Jakarta: Indonesia heritage Foundation, 2007), hal. 93 revitalisasi pendidikan karakter di sekolah.

Yudi Latif mengutip Thomas Lickona mengatakan bahwa: Pendidikan karakter ialah usaha sengaja untuk menolong orang agar memahami, peduli akan dan bertindak atas dasar nilai-nilai etis. Lickona menegaskan bahwa tatkala kita berfikir tentang bentuk karakter yang ingin ditunjukkan anak-anak, teramat jelas bahwa kita menghendaki mereka mampu menilai apa yang benar, peduli apa yang benar serta melakukan apa yang diyakini benar. $^{15}$

Pendidikan karakter ialah sistem penanaman nilai-nilai karakter pada warga sekolah yang meliputi komponen pengetahuan, kesadaran atau kemauan dan tindakan untuk merealisasikan nilai-nilai tersebut. Pendidikan karakter dimaknai sebagai pendidikan nilai, budi pekerti, moral, watak atau pendidikan etika. Tujuannya untuk mengembang kan potensi murid untuk memberikan keputusan baik buruk, memelihara apa yang baik dan mewujudkan kebaikan itu dalam kehidupan sehari-hari.

\section{Tujuan Pendidikan Karakter}

Mardiatmadja menyebut pendidikan karakter sebagai ruh pendidikan dalam memanusiakan manusia. Pemaparan pandangan tokohtokoh menjunjukkan bahwa pendidikan sebagai nilai universal kehidupan memiliki tujuan pokok yang disepakati di setiap zaman, pada setiapkawasan,

\footnotetext{
${ }^{14}$ Ibid,. hal. 37-38

${ }^{15}$ Ibid., hal. 41
} 
dan dalam semua pikiran. Dengan bahasa sederhana, tujuan yang disepakati itu adalah merubah manusia menjadi lebih baik dalam pengetahuan, sikap, dan keterampilan. ${ }^{16}$

Pendidikan karakter bertujuan membentuk dan membangun pola pikir, sikap, dan perilaku peserta didik agar menjadi pribadi yang positif, berakhlak karimah, berjiwa luhur, dan bertanggung jawab. Dalam konteks pendidikan, pendidikan karakter adalah usaha sadar yang dilakukan untuk membentuk peserta didik menjadi pribadi positif dan berakhlak karimah sesuai dengan Standar Kompetendi Lulusan (SKL) sehingga dapat diimplementasikan dalam kehidupan sehari-hari. ${ }^{17}$

Menurut Kemendiknas, tujuan pendidikan karakter antara lain:

a. Mengembangkan potensi nurani atau afektif peserta didik sebagai manusia dan warga negara yang memiliki nilai-nilai budaya dan karakter bangsa.

b. Mengembangkan kebiasaan dan perilaku peserta didik yang terpuji dan sejalan dengan nilai-nilai universal dan tradisi budaya bangsa yang religius.

c. Menanamkan jiwa kepemimpinan dan tanggungjawab siswa sebagai generasi penerus bangsa.

d. Mengembangkan kemampuan siswa untuk menjadi manusia yang mandiri, kreatif, dan berwawasan kebangsaan.

${ }^{16}$ Abdul Majid, Dian Andayani, Pendidikan Karakter Perspektif Islam. (Bandung: PT Remaja Rosdakarya, 2011), hal. 30 e. Mengembangkan lingkungan kehidupan sekolah sebagai lingkungan belajar yang aman, jujur, penuh kreatifitas dan persahabatan, serta dengan rasa kebangsaan yang tinggi dan penuh kekuatan.

\section{Dasar Pembentukkan Karakter}

Manusia pada dasarnya memiliki dua potensi, yakni baik dan buruk. Di dalam Al Qur'an surah Al Syams (91):8 dijelaskan dengan istilah Fujur (celaka atau fasik) dan takwa (takut kepada Tuhan). Manusia memiliki dua kemungkinan jalan, yaitu menjadi makhluk yang beriman atau ingkar terhadap Tuhannya. Keberuntungan berpihak pada orang yang senantiasa menyucikan dirinya dan kerugian berpihak pada orang-orang yang mengotori dirinya, sebagaimana firman Allah dalam Q.S Al-Syams ayat 8 yang artinya "Allah mengilhamkan kepada jiwa itu (jalan) kefasikan dan ketakwaannya".

Manusia adalah makhluk Tuhan yang sempurna. Akan tetapi, ia bisa menjadi hamba yang paling hina dan bahkan lebih hina daripada binatang, sebagaimana keterangan Al-Qur'an Surah At-Tin ayat 4-5 yang artinya sebagai berikut ini:

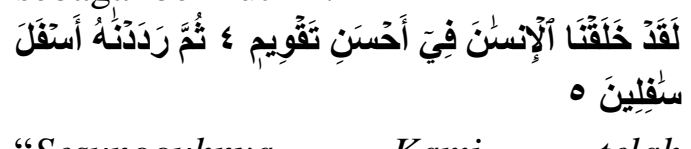

"Sesungguhnya Kami telah menciptakan manusia dalam bentuk yang sebaik-baiknya. Kemudian Kami

${ }^{17}$ Agus Zaenul Fitri, Reinventing Human Character: Pendidikan Karakter Berbasis Nilai \& Etika di Sekolah. (Jogjakarta: Ar-Ruzz Media, 2012), hal. 22-25 
kembalikan dia ke tempat yang serendah- rendahnya (neraka)". ${ }^{18}$

Dengan dua potensi di atas, manusia dapat menentukan dirinya untuk menjadi baik atau buruk. Dalam teori lama yang dikembangkan oleh dunia Barat, disebutkan bahwa perkembangan seseorang hanya dipengaruhi oleh pembawaan (nativisme). Sebagai lawannya, berkembang pula teori yang berpendapat bahwa seseorang hanya ditentukan oleh pengaruh lingkungan (empirisme). Sebagai sistensinya, kemudian dikembangkan teori ketiga yang berpendapat bahwa perkembangan seseorang ditentukan oleh pembawaan dan lingkungan (kovergensi).

\section{Indikator Keberhasilan Pendidikan Karakter}

Menurut Hasan dkk, ada dua jenis indikator yang dikembangkan dalam pedoman ini. Pertama, indikator untuk sekolah dan kelas. Kedua, indikator untuk mata pelajaran. Indikator sekolah dan kelas adalah penanda yang digunakan oleh kepala sekolah, guru, dan personalia sekolah dalam merencanakan, melaksanakan dan mengevaluasi sekolah sebagai lembaga pelaksana pendidikan budaya dan karakter bangsa. Indikator ini berkenaan juga dengan kegiatan sekolah yang diprogramkan dan kegiatan sekolah sehari-hari. Indikator mata pelajaran menggambarkan perilaku afektif seorang peserta didik berkenaan dengan mata pelajaran tertentu. Ada 18 nilai yang harus dikembangkan sekolah dalam menentukan keberhasilan pendidikan karakter, yaitu: 1) Religius, sikap dan perilaku yang patuh dalam melaksanakan ajaran agama yang dianutnya. 2) Jujur, perilaku yang didasarkan pada upaya menjadikan dirinya sebagai orang yang selalu dapat dipercaya dalam perkataan, tindakan, dan pekerjaan. 3) Toleransi, sikap dan tindakan yang menghargai perbedaan agama, suku, etnis, pendapat, sikap, dan tindakan orang lain yang berbeda dari dirinya. 4)Disiplin, tindakan yang menunjukan perilaku tertib dan patuh pada berbagai ketentuan dan peraturan.

5) Kerja keras, perilaku yang menunjukkan upaya sungguh-sungguh dalam mengatasi berbagai hambatan belajar dan tugas, serta menyelesaikan tugas dengan sebaik-baiknya. 6) Kreatif, berpikir dan melakukan sesuatu untuk menghasilkan cara atau hasil baru dari sesuatu yang telah dimiliki. 7) Mandiri, sikap dan perilaku yang tidak mudah bergantung pada orang lain dalam menyelesaikan tugas-tugas. 8) Demokratis, cara berpikir, bersikap, bertindak yang menilai sama hal dan kewajiban dirinya dan orang lain. 9) Rasa ingin tahu, sikap dan tindakan yang selalu berupaya mengetahui lebih mendalam dan meluas dari sesuatu yan dipelajarinya, dilihat dan didengar. 10) Semangat kebangsaan, cara berpikir, bertindak, dan berwawasan yang menempatkan kepentingan bangsa dan negara diatas kepentingan diri dan kelompok nya. 11) Cinta tanah air, cara berpikir, bersikap, dan berbuat yang menunjuk kan kesetiaan kepedulian, dan 5

${ }^{18}$ Al-Qur'an Terjemah Surat At Tin Ayat 4 
dan penghargaan yang tinggi terhadap bangsa, lingkungan fisik, sosial, budaya, ekonomi, dan politik bangsa. 12) Menghargai prestasi, sikap dan tindakan yang mendorong dirinya untuk menghasilkan sesuatu yang berguna bagi masyarakat, dan mengakui, serta menghormati keberhasilan orang lain. 13) Bersahabat atau komunikatif, tindakan yang memperlihatkan rasa senang berbicara, bergaul dan bekerja sama dengan orang lain. 14) Cinta damai, sikap, perkataan dan tindakan yang menyebabkan orang lain merasa senang dan aman atas kehadiran dirinya.

15) Gemar membaca, kebiasaan menyediakan waktu untuk membaca berbagai bacaan yang memberikan kebajikan bagi dirinya. 16) Peduli lingkungan, sikap dan tindakan yang selalu berupaya mencegah kerusakan lingkungan alam disekitarnya, dan mengembangkan upaya untuk memperbaiki kerusakan alam yang sudah terjadi. 17) Peduli sosial, sikap dan tindakan yang selalu ingin memberi bantuan pada orang lain dan masyarakat yang membutuhkan. 18) Tanggung jawab, sikap dan perilaku seseorang untuk melaksanakan tugas dan kewajibannnya yang seharusnya dia lakukan terhadap diri sendiri, masyarakat, lingkungan, negara dan Tuhan Yang Maha Esa. ${ }^{19}$

Menurut Anas Salahudin dan Irwan Alkrieniehie dalam buku Pendidikan Karakter, Pendidikan Berbasis Agama dan Budaya Bangsa, Adapun indikator keberhasilannya

${ }^{19}$ Anas Salahudin, irwan Alkrieniehie, Pendidikan Karakter; Pendidikan Berbasis Agama dapat dikembangkan sebagaimana dicontohkan pada tabel 2.1 berikut:

\begin{tabular}{|c|c|c|}
\hline NO & Nilai & Indikator \\
\hline 1 & Religius & $\begin{array}{l}\text { a. Mengucapkan salam. } \\
\text { b. Berdo'a sebelum dan } \\
\text { sesudah belajar } \\
\text { c. Melaksanakan ibadah } \\
\text { keagamaan. } \\
\text { d. Merayakan hari besar } \\
\text { keagamaan. }\end{array}$ \\
\hline 2 & Jujur & $\begin{array}{l}\text { a. Membuat dan } \\
\text { mengerjakan tugas } \\
\text { secara benar. } \\
\text { b. Tidak mencontek atau } \\
\text { memberi contenkan. } \\
\text { c. Melakukan kegiatan } \\
\text { sekolah secara } \\
\text { transparan. }\end{array}$ \\
\hline 3 & Toleransi & $\begin{array}{l}\text { a. Memperlakukan orang } \\
\text { lain dengan cara yang } \\
\text { sama dan tidak } \\
\text { membeda-bedakan } \\
\text { agama, suku, ras, dan } \\
\text { golongan. } \\
\text { b. Menghargai perbedaan } \\
\text { yang ada tanpa } \\
\text { melecehkan kelompok } \\
\text { yang lain. }\end{array}$ \\
\hline 4 & Disiplin & $\begin{array}{l}\text { a. Siswa hadir tepat waktu. } \\
\text { b. Menjalankan tata tertib } \\
\text { sekolah. }\end{array}$ \\
\hline 5 & $\begin{array}{l}\text { Kerja } \\
\text { keras }\end{array}$ & $\begin{array}{l}\text { a. Mendorong semua } \\
\text { warga sekolah untuk } \\
\text { berprestasi. } \\
\text { b. Berkompetensi secara } \\
\text { fair. }\end{array}$ \\
\hline 6 & Kreatif & $\begin{array}{l}\text { a. Menciptakan ide-ide } \\
\text { baru di sekolah. } \\
\text { b. Menghargai setiap karya } \\
\text { yang unik dan berbeda. } \\
\text { c. Membangun suasana } \\
\text { belajar yang mendorong } \\
\text { munculnya kreativitas } \\
\text { siswa. }\end{array}$ \\
\hline 7 & Mandiri & $\begin{array}{l}\text { a. Melatih siswa agar } \\
\text { mampu bekerja secara } \\
\text { mandiri. } \\
\text { b. Membangun } \\
\text { kemandirian siswa } \\
\text { melalui tugas-tugas yang } \\
\text { bersifat individu. }\end{array}$ \\
\hline
\end{tabular}

dan Budaya Bangsa, (Bandung: CV Pustaka Setia, 2013). Hal 111-112 


\begin{tabular}{|c|c|c|}
\hline 8 & $\begin{array}{l}\text { Demo } \\
\text { kratis }\end{array}$ & $\begin{array}{l}\text { a. Tidak memaksakan } \\
\text { kehendak kepada orang } \\
\text { lain. } \\
\text { b. Sistem pemilihan ketua } \\
\text { kelas dan pengurus kelas } \\
\text { secara demokratis. } \\
\text { c. Mendasarkan setiap } \\
\text { keputusan pada } \\
\text { musyawarah mufakat. }\end{array}$ \\
\hline 9 & $\begin{array}{l}\text { Rasa ingin } \\
\text { tahu }\end{array}$ & $\begin{array}{l}\text { a. Sistem pembelajaran } \\
\text { diarahkan untuk } \\
\text { mengeksplorasi } \\
\text { keingintahuan siswa. } \\
\text { b. Sekolah memberikan } \\
\text { fasilitas, baik melalui } \\
\text { media cetak maupun } \\
\text { elektronik, agar siswa } \\
\text { dapat mencari informasi } \\
\text { yang baru. }\end{array}$ \\
\hline 10 & $\begin{array}{l}\text { Semangat } \\
\text { kebangsaa } \\
\text { an }\end{array}$ & $\begin{array}{l}\text { a. Memperingati hari-hari } \\
\text { besar nasional. } \\
\text { b. Meneladani para } \\
\text { pahlawan nasional. } \\
\text { c. Berkunjung ke tempat- } \\
\text { tempat bersejarah. } \\
\text { d. Melaksanakan upacara } \\
\text { rutin sekolah. } \\
\text { e. Mengikutsertakan dalam } \\
\text { kegiatan-kegiatan } \\
\text { kebangsaan. } \\
\text { f. Memajang gambar } \\
\text { tokoh-tokoh bangsa. }\end{array}$ \\
\hline 11 & $\begin{array}{l}\text { Cinta } \\
\text { tanah air }\end{array}$ & $\begin{array}{l}\text { a. Menanamkan } \\
\text { nasionalisme dan rasa } \\
\text { persatuan dan kesatuan } \\
\text { bangsa. } \\
\text { b. Menggunakan bahasa } \\
\text { Indonesia dengan baik } \\
\text { dan benar. } \\
\text { c. Memajang bendera } \\
\text { Indonesia, Pancasila, } \\
\text { gambar presiden serta } \\
\text { simbol-simbol negara } \\
\text { lainnya. } \\
\text { d. Melestarikan seni dan } \\
\text { budaya bangsa. }\end{array}$ \\
\hline 12 & $\begin{array}{l}\text { Menghar } \\
\text { gai } \\
\text { Prestasi }\end{array}$ & $\begin{array}{ll}\text { a. } & \text { Mengabadikan dan } \\
\text { memajang hasil karya } \\
\text { siswa di sekolah } \\
\text { b. } \\
\text { gelatih dan membina } \\
\text { generasi penerus untuk } \\
\text { mencontoh hasil atau } \\
\text { prestasi generasi } \\
\text { sebelumnya. }\end{array}$ \\
\hline 13 & $\begin{array}{l}\text { Bersaha } \\
\text { bat/komu } \\
\text { nikatif }\end{array}$ & $\begin{array}{l}\text { a. Saling menghargai dan } \\
\text { menghormati. } \\
\text { b. menyayangi Guru dan } \\
\text { menghormati guru. }\end{array}$ \\
\hline
\end{tabular}

\begin{tabular}{|c|c|c|}
\hline & & $\begin{array}{ll}\text { c. } & \text { Tidak menjaga jarak. } \\
\text { d. } & \text { Tidak membeda- } \\
\text { bedakan dalam } \\
\text { berkomunikasi. }\end{array}$ \\
\hline 14 & $\begin{array}{l}\text { Cinta } \\
\text { damai }\end{array}$ & \begin{tabular}{|l} 
a. \\
Menciptakan suasana \\
b. \\
Tidak menoleransi \\
segala bentuk tindak \\
kekerasan \\
c. \\
Mendorong terciptanya \\
harmonisasi kelas dan \\
sekolah.
\end{tabular} \\
\hline 15 & $\begin{array}{l}\text { Gemar } \\
\text { membaca }\end{array}$ & 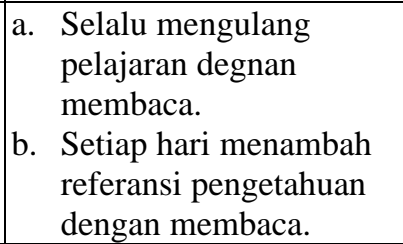 \\
\hline 16 & $\begin{array}{l}\text { Peduli ling } \\
\text { kungan }\end{array}$ & \begin{tabular}{|ll} 
a. & Menjaga lingkungan \\
& kelas dan sekolah. \\
b. & Memlihara tumbuh- \\
& tumbuhan dengan baik \\
& tanpa menginjak atau \\
& merusaknya. \\
c. & Mendukung program go \\
& green (penghijauan) \\
dilingkungan sekolah. \\
d. & Membuang sampah \\
& organik dan sampah non \\
& organik.
\end{tabular} \\
\hline 17 & $\begin{array}{l}\text { Peduli } \\
\text { sesama }\end{array}$ & 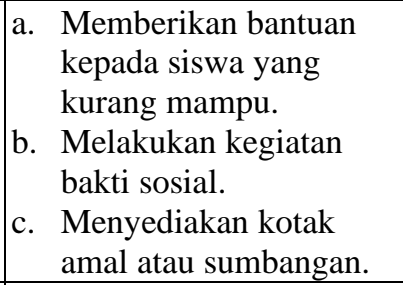 \\
\hline 18 & $\begin{array}{l}\text { Tanggung } \\
\text { jawab }\end{array}$ & 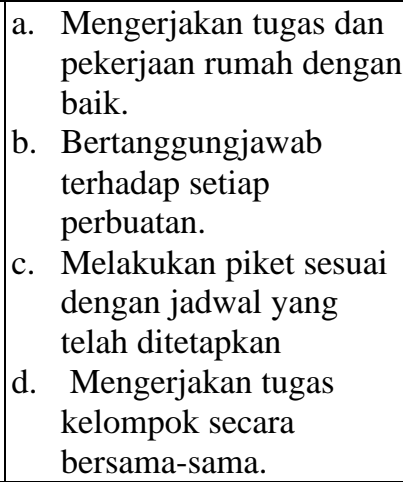 \\
\hline
\end{tabular}

\section{Pengertian Etiket}

Menurut kamus besar bahasa Inbdonesia, Etiket adalah tata cara (Adat sopan santun, dsb) dalam mastarakat beradab dalam memelihara hubungan baik antara sesama manusia. 
Secara etimologis kata etika berasal dari bahasa yunani yaitu dari kata ethos yang berarti adat atau kebiasan baik yang tetap. Orang yang pertama kali mrnggunakan kata- kata ini adalah seorang filosof yunani yang bernama Aristoteles (384-322SM) Dikatakan dalam kamus bahasa Indonesia (KBBI) bahwa etika adalah ajaran tentang baik dan buruk mengenai perbuatan, sikap, kewajiban dan sebagainya. ${ }^{20}$

Menyangkut etika dan etiket, pada prinsipnya terdapat perbedaan yang sangat signifikan, terutama dalam kehidupan sehari-hari. Hal ini sesuai pendapat Bartens yang mengemukakan empat perbedaan antara etika dan etiket: $^{21}$

\begin{tabular}{|c|c|}
\hline Etika & Etiket \\
\hline $\begin{array}{l}\text { Etika } \\
\text { menetapkan } \\
\text { norma } \\
\text { perbuatan, } \\
\text { apakah } \\
\text { perbuatan boleh } \\
\text { dilakukan/ } \\
\text { tidak. Misalnya, } \\
\text { masuk rumah } \\
\text { or-ang tanpaizin } \\
\end{array}$ & $\begin{array}{l}\text { Etiket menetapkan } \\
\text { cara melakukan } \\
\text { perbuatan, }\end{array}$ \\
\hline 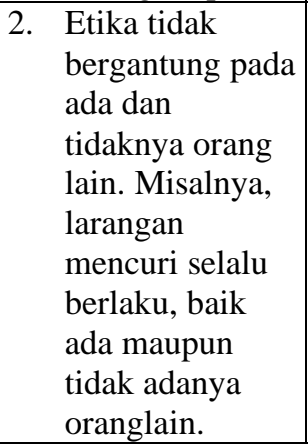 & $\begin{array}{l}\text { 2. Etiket hanya berlaku } \\
\text { dalam pergaulan, jika } \\
\text { tidak ada orang lain } \\
\text { yang hadir makaetiket } \\
\text { tidak berlaku. Misal- } \\
\text { nya, makan tanpa baju. } \\
\text { Jika makan sendiri } \\
\text { tanpa orang lain maka } \\
\text { telanjangpun tidak } \\
\text { masalah }\end{array}$ \\
\hline $\begin{array}{l}\text { 3. Etika bersifat } \\
\text { absolut, } \\
\text { tidakdapat } \\
\text { ditawar } \\
\text { misalnya } \\
\text { mencuri } \\
\text { membunuh. }\end{array}$ & $\begin{array}{l}\text { 3. Etiket bersifat relatif, } \\
\text { yang dianggap tidak } \\
\text { sopan dalam suatu } \\
\text { kebudayaan dapat saja } \\
\text { dianggap sopan oleh } \\
\text { kebudayaanlain. }\end{array}$ \\
\hline
\end{tabular}

${ }^{20}$ Heri Gunawan, Pendidikan Karakter Konsep dan Implementasi (Bandung: ALFABETA, 2014) hlm. 14

\footnotetext{
${ }^{21}$ Abdullah dan Safarina, Etika Pendidikan Keluarga sekolah dan Masyarakat, PT. Raja Grafindo Persada, Jakarta, 2016, hlm. 88-89

${ }^{22}$ Onita Alya, Kamus Bahasa Indonesia, (PT. Indah Jaya Adi Pratama, 2011), hal.274
}

\begin{tabular}{|c|c|}
\hline & $\begin{array}{l}\text { Contoh, memegang } \\
\text { kepala orang lain di } \\
\text { Indonesia tidak } \\
\text { sopan, sedangkan di } \\
\text { Amerika biasa saja }\end{array}$ \\
\hline $\begin{array}{l}\text { 4. Etika } \\
\text { memandang } \\
\text { manusia dari } \\
\text { segi dalam } \\
\text { (bathiniah), } \\
\text { orang yang } \\
\text { bersikap etis } \\
\text { adalah orang } \\
\text { yang benar- } \\
\text { benar baik, sifat } \\
\text { nya tidak } \\
\text { munafik. }\end{array}$ & $\begin{array}{l}\text { 5. Etiket memandang } \\
\text { manu-sia dari segi } \\
\text { luar (lahiriah), } \\
\text { tampaknya dari luar } \\
\text { sopan dan halus, } \\
\text { tetapi didalam } \\
\text { dirinya penuh } \\
\text { kebusu-kan } \\
\text { dankemunafikan }\end{array}$ \\
\hline
\end{tabular}

Dalam Kamus Besar Bahasa Indonesia, sopan santun dapat diartikan sebagai berikut: Sopan: hormat dengan tak lazim (akan, kepada) tertib menurut adab yang baik, bisa dikatakan juga sebagai cerminan kognitif (pengetahuan). Santun: halus dan baik (budi bahasanya, tingkah lakunya); sopan, sabar; tenang. ${ }^{22}$ Atau bisa dikatakan cerminan psikomotorik (penerapan pengetahuan sopan ke dalam suatu tindakan) Jika digabungkan kedua kalimat tersebut, sopan santun adalah pengetahuan yang berkaitan dengan penghormatan melalui sikap, perbuatan atau tingkah laku, budi pekerti yang baik, sesuai dengan tata krama, peradaban, dan kesusilaan. Orang yang mempunyai sifat santun, berati ia tahu akan adab-adab kesopanan. Orang yang santun disegani banyak orang. Perilaku halus, tutur katanya lembut, dan tidak pernah menyakiti hati orang lain. Orang yang santun sangat menjaga kesopanan dalam pergaulan sehari-hari. Contoh perbuatan santun, antara lain apabila bertemu orang yang lebih tua menyapa 
dengan hormat, tidak berbicara kasar kepada orang lain, tidak suka melawan orang tua, dan patuh kepada guru. Kebalikan sifat santun adalah sifat kurang ajar. Orang yang memiliki sifat kurang ajar akan dijauhi teman dan dibenci orang lain. Contoh perbuatan kurang ajar, antara lain suka berbicara kasar, tidak menghormati orang tua, dan tidak mematuhi guru. Jika terbiasa bersikap santun dalam pergaulan seharihari, kita akan memiliki banyak teman an disukai orang lain. Orang lain akan menyebut diri kita sebagai anak yang berbudi pekerti luhur. ${ }^{23}$

Tata peraturan kesopanan yang semula berlaku dalam lingkungan terbatas lama kelamaan dapat merambat ke lingkungan masyarakat yang lebih luas. Perkembangan itu secara perlahalahan tanpa diarahkan dan pada akhirnya diterima sebagai suatu kesepakatan bersama, suatu perjanjian tak tertulis, suatu konvensi. Dengan mengalirnya waktu, tanpa sadar muncul kesepakatan tertentu yang tersaring dari kungkungan lingkungan masyarakat setempat, masyarakat wilayah tertentu, dan pada akhirnya diterima sebagai kebiasaan yang berlaku sebagai kebiasaa. ${ }^{24}$ Sopan santun atau tata krama adalah suatu tata cara atau aturan yang turun temurun dan berkembang dalam suatu budaya masyarakat, yang bermanfaat dalam pergaulan dengan orang lain, agar terjalin hubungan yang akrab, saling pengertian, hormat-menghormati menurut adat yang ditentukan. ${ }^{25}$

Berdasarkan uraian di atas dapat disimpulkan bahwa sopan santun

${ }^{23}$ Wiyadi, Membina Akidah Akhlak (Solo: PT Tiga Serangkai, 2010), hal 34-35

${ }^{24}$ Conny semiawan, A.f. Tangyong, S. Ballen, dan Darmiati, Tata krama Pergaulan, (Jakarta, Balai Pustaka: 1987) hal 15-16

${ }^{25}$ Suharti, Pendidikan Sopan Santun Dan Kaitannya Dengan Perilaku Berbahasa Jawa merupakan perilaku seseorang yang menjunjung tinggi nilai-nilai menghormati, menghargai, tidak sombong dan berakhlak mulia dengan cara menghormati orang yang lebih tua, menyapa jika bertamu dengan orang lain, berbicara dengan nada lembut dan berbahasa yang santun, serta berperilaku yang baik. Dengan kata lain sopan santun adalah peraturan hidup yang timbul dari hasil pergaulan sekelompok individu atau masyarakat yang membentuk suatu sistem etika atau moral.

Aspek-aspek perilaku sopan satun ini merupakan hal-hal yang harus diperhatikan dengan jelas oleh siswa terutama dalam pergaulannya seharihari, Aspek- aspek perilaku tersebut yaitu: a)tata krama dengan Allah SWT, ${ }^{26}$ b)tata krama bergaulan dengan orangtua, c)tata krama bergaul dengan guru di sekolah, d)tata krama bergaul dengan orang yang lebih tua, e)tata krama bergaul dengan orang yang lebih muda, f)tata krama bergaul dengan teman sebaya, g)tata krama bergaul dengan lawan jenis, h)sopan santun berbicara, i) sopan santun Terhadap binatang, j)sopan santun terhadap tumbuh-tumbuhan, dan k)sopan santun terhadap benda-benda. ${ }^{27}$

\section{Faktor Yang Mempengaruhi Perilaku etiket (Sopan Santun)}

Faktor-faktor perilaku sopan santun dapat terbentuk sejak dini melalui beberapa faktor, antara lain:

a. Faktor orang tua

Keluarga adalah tempat terbentuknya akhlak yang terbaik

Mahasiswa. (Yogyakarta: DIKSI 2004) Vol, 11, No 1. Hal 59

${ }^{26}$ Syafaruddin, Tim Editor Bahan Ajar PLPG Pendidikan Agama Islam. (Medan: FITK Universitas Islam Negeri Sumatera Utara) Hal 134

${ }^{27}$ M Quraish Shihab. Yang Hilang Dari Kita Ahlak. (Tanggerang: Lentera Hati 2016). hal.289 
dibandingkan tempat pendidikan yang lain. Hal ini karena melalui keluarga, orangtua dapat memberikan penanaman akhlak sedini mungkin kepadaanakanaknya. Dari lingkungan keluarga pembentuk perilaku sopan santun mudah diterima oleh anak karena komunikasi yang terjadi setiap waktu antara orangtua dan anak, melalui perhatian, kasih sayang, serta penerapan perilaku dalam sikap sopan santun yang baik dari pengajaran orang tua kepada anaknya berlangsung secara alami karena dilakukan dengan kasih sayang dan cinta yang tulus dari orang tua kepada anak-anaknya.

b. Faktor lingkungan

Manusia sebagai makhluk sosial tidak bisa dipisahkan dari interaksi antar sesama. Kesamaan prinsip dan tujuan akan sesuatu menjadikan adanya kedekatan antar satu dengan yang lainnya sehingga terbentuklah lingkungan pergaulan.

c. Faktor sekolah

Sekolah berperan sebagai wahana penyampaian pendidikan dan pengajaran yang turut serta berperan dalam mempengaruhi tingkat pengembangan perilaku sopan santun seorang anak. Peran guru sebagai penyampai ilmu sangatlah penting. Seorang guru tidak hanya memberikan pendidikan dalam bentuk materi saja, tetapi lebih dari itu harus dapat mencontohkan sisi teladannya. Disamping itu, guru juga harus memberikan contoh yang baik dalam sosialisasi kehidupan. Hal ini dikarenakan perilaku seorang gurulah yang pertama-tama dilihat oleh siswanya. Dari uraian di atas dapat disimpulkan bahwa faktor yang mempengaruhi perilaku sopan santun dapat memberikan informasi bahwasanya ada saling berkaitan faktor orangtua, faktor lingkungan dan faktor sekolah dalam membentuk perilaku sopan santun yang baik maupun yang buruk, dan tidak tergantung pada satu faktor saja melainkan ketiga faktor tersebut saling melengkapi.

\section{Macam-Macam (Kesopanan)}

Etiket

a. Kesopanan Berbahasa

Santun bahasa menunjukkan bagaimana seseorang melakukan interaksi sosial dalam kehidupannya secara lisan. Setiap orang harus menjaga santun bahasa agar komunikasi dan interaksi dapat berjalan baik. Bahasa yang dipergunakan dalam sebuah komunikasi sangat menentukan keberhasilan pembicaraan. Seperti diterangkan dalam ayat al-Quran:

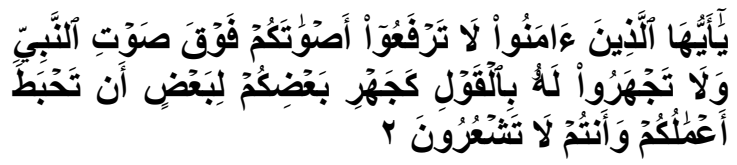

Hai orang-orang yang beriman, janganlah kamu meninggikan suaramu melebihi suara Nabi, dan janganlah kamu berkata kepadanya dengan suara yang keras, sebagaimana kerasnya suara sebagian kamu terhadap sebagian yang lain, supaya tidak hapus (pahala) amalanmu, sedangkan kamu tidak menyadari. (Q.S, Al-Hujurat: 2$)^{28}$

Dari ayat di atas dapat dijelaskan bahwa islam sangat memperhatikan dan mengatur sikapperilaku, adab sopan santun yang harus dikedepankan oleh umat islam ketika berhadapan dengan Nabi Muhammad SAW, secara lebih luas ayat ini dapat menjabarkan bahwa ketika kita sedang berhadapan dengan orang yang lebih tua baik dari segi intelektualnya maupun dari segi jabatannya serta dalam kondisi

${ }^{28}$ Kementerian Agama RI, Al-Qur'an Dan Terjemahnya (Bandung: Cordoba Internasional Indonesia2012), Hal. 515. 
musyawarah maupun dalam kondisi di tengah-tengah masyarakat kita harus berlaku sopan dan santun.

b. Sopan Santun Berperilaku

Santun adalah satu kata sederhana yang memiliki arti banyak dan dalam, berisi nilai-nilai positif yang dicerminkan dalam perilaku dan perbuatan positif. Perilaku positif lebih dikenal dengan santun yang dapat diimplementasikan pada cara berbicara, cara berpakaian, cara memperlakukan orang lain, cara mengekspresikan diri dimanapun dan kapan pun. Santun juga merupakan sifat halus dan baik dari sudut pandang tata bahasa maupun tata perilakunya ke semua orang.

c. Sopan Santun Terhadap Orang tua

Setiap orang tua harus mengajari anaknya untuk bersikap sopan santun (beretika) dan berbakti kepada kedua orang tuanya. Jika bersikap sopan santun merupakan hal yang sudah sepatutnya dilakukan terhadap orang lain apalagi terhadap orang tua yang telah sangat berjasa dalam kehidupan kita di dunia ini, orang tua telah mengasuh serta membesarkan dan merawat anaknya hingga anaknya dewasa. Jangan sampai melakukan sikap yang tidak sepantasnya dan bersikap tidak sopan santun terhadap orang tua. ${ }^{29}$ Sebagaimana hal itu secara tegas telah diperintahkan Allah SWT dalam Al-Quran, sebagai berikut:

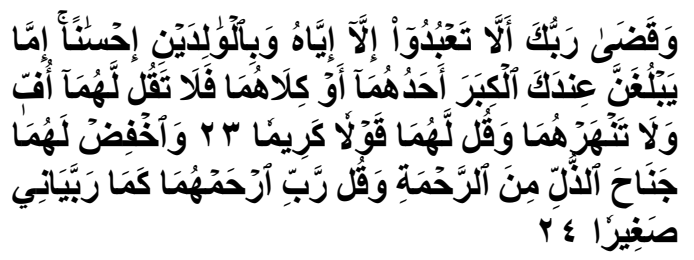

${ }^{29}$ Saiful Hadi El-Sutha. (2015). Pintar Mendidik Anak Ala Rasulullah (Tuntunan Mendapatkan Anak Shaleh/Shalehah Dari Fase Pra Hamil Hingga Usia Remaja). Jakarta: Radar Jaya Offset. Hal 212
"Dan Tuhanmu memerintahkan kamu supaya jangan menyembah selain Dia (Allah) dan hendaklah kamu berbuat baik kepada ibu bapakmu, dengan sebaik-baiknya. Dan rendahkanlah dirimu terhadap mereka berdua dengan penuh kesayangan dan ucapkanlah: "Wahai Tuhanku, kasihilah mereka keduanya, sebagaimana mereka berdua telah mendidik aku waktu kecil". (Q.S. Al-Isra: 23-24). ${ }^{30}$

Dari ayat di atas dapat dijelaskan bahwa karakter pendidikan islam adalah berbuat baik dan berbakti kepada orang tua. Seorang anak sudah semestinya untuk selalu berlaku sopan dan santun kepada orang tua. Tidak tanpa terkecuali karena sudah jelas bahwa orangtualah yang sudah memberi sepenuhnya kasih sayang kepada anak. Sebagai orangtua pun juga harus memberikan didikan yang baik serta sesuai dengan nilai-nilai agama, karena semua itu demi kebaikan orang tua serta anak. Dengan demikian suatu karakter pendidikan dalam islam bisa tercipta dengan baik jika kedua pihak saling menunjukkan keharmonisan hubungan dengan dasar-dasar pendidikan yang dibentuk sebaik-baiknya. Banyak sekali yang memang sudah melupakan arti dari menghormati orang tua, saat ini mulai banyak anak yang tidak tahu sopan santun saat berbicara pada orang tuanya. Seorang anak padahal dituntut berbuat baik kepada orang tua dengan berkata secara mulia, bertingkah laku sopan dan santun, serta memperlakukan orang tua dengan sebaik - baiknya.

\footnotetext{
${ }^{30}$ Kementerian Agama RI, Al-Qur'an Dan Terjemahnya. (Bandung: Cordoba Internasional Indonesia 2012), Hal. 515.
} 


\section{d. Sopan Santun Murid}

Hal-hal yang menjadi perhatian bagi murid: 1) menyingkirkan akhlak buruk atau menghiasi diri dengan budi pekerti karena budi pekerti mendahului ilmu, 2) mengurangi hal-hal yang dapat menghambat terperolehnya ilmu, 3) jangan angkuh baik terhadap guru maupun ilmu. ${ }^{31}$ Terkait dengan hal ini Rasulullah SAW memotivasi untuk menuntut ilmu dalam sebuah hadits sebagai berikut:

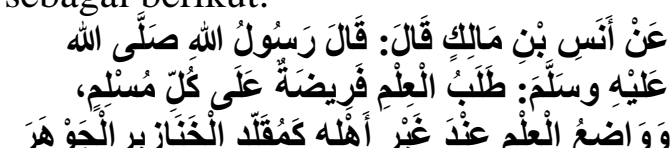

"Dari Anas bin Maliki r.a, dia berkata: Rasulullah SAW bersabda, "Menuntut ilmu merupakan kewajiban bagi setiap muslim dan orang yang memberikan ilmu kepada orang yang bukan ahlinya seperti orang yang mengikatkan batu permata, mutiara dan emas pada babi."(HR. Ibnu Majah $)^{32}$

Dari hadis di atas dapat dijelaskan bahwa menuntut ilmu merupakan hal yang wajib bagi seluruh umat muslim karena ilmu merupakan jalan mempermudah kita untuk ke surga, allah menginginkan kebaikan dari setiap penuntut ilmu, ilmu merupakan amalan yang dapat dijadikan aset di akhirat nanti serta menuntut ilmu dikira antara ibadah dan jihad.

\section{B. METODOLOGI}

Rancangan dalam penelitian ini menggunakan metode kuantitatif. Subjek penelitian ini adalah seluruh siswa di Madrasah Ibtidaiyah Nurul Huda Parit 5 Sungai Luar kecamatan Batang Tuaka. Objek penelitian ini adalah pengaruh pengetahuan Pendidikan Karakter terhadap etiket siswa di Madrasah Ibtidaiyah Nurul

${ }^{31} \mathrm{M}$ Quraish Shihab. Yang Hilang Dari Kita Akhlak. (Tanggerang: Lentera Hati, 2016). Hal. 246
Huda Parit 5 Sungai Luar Kecamatan Batang Tuaka.

Peneliti menggunakan dua variabel, yaitu: Variabel Bebas (Independen Variable) atau biasa disebut variabel $\mathrm{X}$ adalah pengetahuan pendidikan earakter. Dan Variabel Terikat (Dependen Variable) atau biasa disebut dengan variabel $\mathrm{Y}$ adalah Etiket siswa, peneliti menyesuaikan kategori siswa yang ingin diteliti, Maka populasi terbatas karena yang diteliti hanya peserta didik yang ada pada kelas 4 dan 5 di Madrasah Ibtidaiyah Nurul Huda Parit 5 Sungai Luar Kecamatan Batang Tuaka tahun ajaran 2018/2019 yang berjumlah 33 orang siswa. Dari jumlah keseluruhan 111 orang siswa dengan rincian jumlah 55 orang siswa laki-laki dan 56 orang siswa perempuan menggunakan jenis sampel yang digunakan dalam penelitian ini adalah sampel jenuh.

Teknik yang digunakan dalam pengumpulan data dalam penelitian ini adalah Angket (Kuesioner) Dokumentasi, untuk mengetahui ada tidaknya pengaruh pengetahuan pendidikan karakter etiket siswa di Madrasah Ibtidaiyah Nurul Huda Parit 5 Desa Sungai Luar Kecamatan Batang Tuaka, maka penulis menggunakan teknik analisis data Uji Regresi. Berikut beberapa langkah-langkah Uji Regresi yaitu:

1. Membuat $\mathbf{H}_{\mathbf{a}}$ dan $\mathbf{H}_{\mathbf{0}}$ dalam bentuk kalimat.

2. Membuat $\mathrm{H}_{\mathrm{a}}$ dan $\mathrm{H}_{0}$ dalam bentuk statistika.

3. Membuat tabel penolong untuk menhitung angka statistik.

4. Memasukkan angka-angka statistik dari tabel penolong kedalam rumus:

a. Menghitung rumus $b$

\footnotetext{
${ }^{32}$ Ibnu Hajar Al-Asqalani, Ringkasan Targhib wa Tarhib. (Jakarta: Pustaka Azzam, 2006) Hal. 27
} 
$\mathbf{b}=\mathbf{n} \cdot \sum \mathbf{X Y}-\sum \mathbf{X} \cdot \sum \mathbf{Y}$

$$
\text { n. } \overline{\sum X^{2}-\left(\sum X\right)^{2}}
$$

b. Menghitung rumus a

$$
\mathbf{a}=\frac{\mathbf{n} \cdot \sum \mathbf{Y}-\mathbf{b} \cdot \sum \mathbf{X}}{\mathbf{n}}
$$

c. Menghitung persamaan regresi sederhana

$$
\mathrm{Y}=\mathrm{a}+\mathrm{b} \mathrm{X}
$$

d. Membuat garis persamaan regresi

1). Menghitung rata-rata $X$ dengan rumus:

$$
\mathbf{X}=\frac{\sum \mathrm{X}}{\mathbf{n}}
$$

2). Menghitung rata-rata $X$ dengan rumus:

$$
\mathbf{Y}=\frac{\sum \mathbf{Y}}{\mathbf{n}}
$$

5. Mencari jumlah kuadrad regresi $\left(\mathrm{Jk}_{\text {reg(a) }}\right)$ dengan rumus:

$\mathrm{Jk}_{\mathrm{reg}(\mathrm{a})}=\left(\sum \mathrm{Y}\right)^{\mathbf{2}}$

$$
\text { n }
$$

6. Mencari jumlah kuadrad regresi ( $\left.\mathrm{Jk}_{\text {reg(bla) }}\right)$ dengan rumus:

$$
\left(\mathbf{J k}_{\mathbf{r e g}(\mathbf{b} \mid \mathbf{a})}\right)=\mathbf{b} \cdot\left\{\sum \mathrm{XY}-\frac{(\Sigma \mathrm{X}) \cdot(\Sigma \mathrm{Y})}{\mathbf{n}}\right\}
$$

7. Mencari jumlah kuadrad residu ( $\left.\mathrm{JK}_{\mathrm{Res}}\right)$ dengan rumus:

$\mathbf{J K}_{\text {Res }}=\sum \mathbf{Y}^{\mathbf{2}}-\mathbf{J} \mathbf{k}_{\text {reg(bla) }}-\mathbf{J} \mathbf{k}_{\text {reg(a) }}$

8. Mencari rata-rata jumlah kuadrat regresi( $\left(R K_{\text {Reg(a) }}\right)$ dengan rumus:

$\mathrm{RJK}_{\operatorname{Reg}(\mathrm{a})}=\mathrm{JK}_{\mathrm{Reg}(\mathrm{a})}$

9. Mencari rata-rata jumlah kuadrat regresi $\left(\mathrm{RJK}_{\mathrm{Reg}(\mathbf{b} \mid \mathbf{a})}\right)$ dengan rumus:

$\left(\mathbf{R J K}_{\mathbf{R e g}(\mathbf{b} \mid \mathbf{a})}\right)=\mathbf{J K}_{\mathbf{R e g}(\mathbf{b} \mid \mathbf{a})}$

10. Mencari rata-rata jumlah kuadrat residu RJKRes)dengan rumus:

$$
\left(\mathbf{R J K}_{\text {Res }}\right)=\frac{\mathbf{J K}}{\mathbf{n}-\mathbf{2}}
$$

11. Menguji signifikan dengan rumus:

$F_{\text {hitung }}=\underline{R_{\text {RKeg(bla) }}}$

$$
\text { RJKRes }
$$

12. Membuat kesimpulan ${ }^{33}$

\section{PEMBAHASAN}

\section{Langkah Pertama}

Membuat $\mathbf{H a d a n}_{\mathbf{H}} \mathbf{H}_{\mathbf{0}}$ dalam bentuk kalimat di bawah ini:

$\mathbf{H}_{\mathbf{a}}$ : Terdapat Pengaruh pengetahuan pendidikan karakter terhadap etiket siswa di Madrasah Ibtidaiyah Nurul Huda Parit 5 Desa Sungai Luar Kecamatan Batang Tuaka.

Ho: Tidak terdapat Pengaruh pengetahuan pendidikankarakter terhadap etiket siswa di Madrasah Ibtidaiyah Nurul Huda Parit 5 Desa Sungai Luar Kecamatan Batang Tuaka.

\section{Langkah Kedua}

Membuat $\mathrm{H}_{\mathrm{a}}$ dan $\mathrm{H}_{0}$ dalam bentu statistika, yaitu:

$$
\begin{aligned}
& \mathrm{H}_{\mathrm{a}}: \mathrm{r} \neq 0 \\
& \mathrm{H}_{0}: \mathrm{r}=0
\end{aligned}
$$

\section{Langkah Ketiga}

Membuat tabel penolong untuk menhitung angka statistik dengan cara sebagai berikut:

\begin{tabular}{|c|c|c|c|c|c|}
\hline No. & $\mathbf{X}$ & $\mathbf{Y}$ & $\mathbf{X . Y}$ & $\mathbf{X}^{\mathbf{2}}$ & $\mathbf{Y}^{\mathbf{2}}$ \\
\hline 1. & 128 & 43 & 5504 & 16384 & 1849 \\
\hline 2. & 129 & 43 & 5547 & 16641 & 1849 \\
\hline 3. & 127 & 42 & 5334 & 16129 & 1764 \\
\hline 4. & 120 & 35 & 4200 & 14400 & 1225 \\
\hline 5. & 118 & 39 & 4602 & 13924 & 1521 \\
\hline 6. & 112 & 36 & 4032 & 12544 & 1296 \\
\hline 7. & 103 & 36 & 3708 & 10609 & 1296 \\
\hline 8. & 101 & 36 & 3636 & 10201 & 1296 \\
\hline 9. & 107 & 36 & 3852 & 11449 & 1296 \\
\hline 10. & 98 & 38 & 3724 & 9604 & 1444 \\
\hline 11. & 102 & 34 & 3468 & 10404 & 1156 \\
\hline 12. & 97 & 36 & 3492 & 9409 & 1296 \\
\hline 13. & 102 & 36 & 3672 & 10404 & 1296 \\
\hline 14. & 98 & 33 & 3234 & 9604 & 1089 \\
\hline 15. & 97 & 32 & 3104 & 9409 & 1024 \\
\hline 16. & 96 & 34 & 3264 & 9216 & 1156 \\
\hline 17. & 131 & 43 & 5633 & 17161 & 1849 \\
\hline 18. & 126 & 43 & 5418 & 15876 & 1849 \\
\hline 19. & 117 & 41 & 4797 & 13689 & 1681 \\
\hline 20. & 119 & 38 & 4522 & 14161 & 1444 \\
\hline
\end{tabular}

${ }^{33}$ Ibid, hal. 244 


\begin{tabular}{|c|c|c|c|c|c|}
\hline 21. & 113 & 37 & 4181 & 12769 & 1369 \\
\hline 22. & 102 & 37 & 3774 & 10404 & 1369 \\
\hline 23. & 106 & 37 & 3922 & 11236 & 1369 \\
\hline 24. & 107 & 38 & 4066 & 11449 & 1444 \\
\hline 25. & 105 & 33 & 3465 & 11025 & 1089 \\
\hline 26. & 108 & 37 & 3996 & 11664 & 1369 \\
\hline 27. & 108 & 36 & 3888 & 11664 & 1296 \\
\hline 28. & 109 & 35 & 3815 & 11881 & 1225 \\
\hline 29. & 102 & 31 & 3162 & 10404 & 961 \\
\hline 30. & 99 & 32 & 3168 & 9801 & 1024 \\
\hline 31. & 98 & 31 & 3038 & 9604 & 961 \\
\hline 32. & 102 & 32 & 3264 & 10404 & 1024 \\
\hline 33. & 99 & 33 & 3267 & 9801 & 1089 \\
\hline & $\begin{array}{l}\sum X \\
=35 \\
86\end{array}$ & $\begin{array}{l}\sum Y= \\
1203\end{array}$ & $\begin{array}{l}\sum X Y \\
= \\
1317 \\
49\end{array}$ & $\begin{array}{l}\sum X^{2}= \\
393324\end{array}$ & $\begin{array}{l}\sum Y^{2}= \\
\mathbf{4 4 2 6} \\
5\end{array}$ \\
\hline
\end{tabular}

\section{Langkah Keempat}

Memasukkan angka-angka statistik dari tabel penolong kedalam rumus:

e. Menghitung rumus $b$

$$
\begin{aligned}
& \mathbf{b}=\frac{\mathbf{n} \cdot \sum X Y-\sum X \cdot \sum Y}{\mathbf{n} \cdot \sum X^{2}-\left(\sum X\right)^{2}} \\
& \mathbf{b}=\frac{33.131749-3586.1203}{33.393324-(3586)^{2}} \\
& b=\frac{4347717-4313958}{12979692-12859396} \\
& b=\frac{33759}{120296} \\
& b=\mathbf{0 , 2 8 . 8 8}
\end{aligned}
$$

Dengan demikian diketahui nilai $b$ $=0,29$.

f. Menghitung rumus a

$$
\begin{aligned}
& \mathbf{a}=\frac{\mathbf{n} \cdot \sum Y-b \cdot \sum X}{\mathbf{n}} \\
& \mathbf{a}=\frac{33.1203-0,28.3586}{33} \\
& \mathbf{a}=\frac{39699-1004,08}{33}
\end{aligned}
$$

$$
\begin{aligned}
& \mathbf{a}=\frac{\mathbf{3 8 6 9 4 , 9 2}}{\mathbf{3 3}} \\
& \mathbf{a}=\mathbf{1 1 7 2 , 5 7} \\
& \text { Dengan demikian diketahui nilai a } \\
& =1171,49 .
\end{aligned}
$$

g. Menghitung persamaan regresi sederhana

$$
\begin{aligned}
& Y=a+b X \\
& =1172,57+(0,28)(X)
\end{aligned}
$$

h. Membuat garis persamaan regresi 1). Menghitung rata-rata $X$ dengan rumus:

$$
\begin{aligned}
& X=\frac{\sum X}{n} \\
& X=\frac{3586}{33} \\
& X=108,67
\end{aligned}
$$

2). Menghitung rata-rata $X$ dengan rumus:

$$
\begin{aligned}
Y & =\frac{\sum Y}{n} \\
Y & =\frac{1203}{33} \\
Y & =36,46
\end{aligned}
$$

\section{Langkah Kelima}

Mencari jumlah kuadrad regresi $\left(\mathrm{Jk}_{\mathrm{reg}(\mathrm{a})}\right)$

$$
J_{k_{\text {reg(a) }}}=\frac{(\Sigma Y)^{2}}{n}
$$

$\mathrm{Jk}_{\mathrm{reg}(\mathrm{a})}=\left(\underline{\mathbf{1 2 0 3}}^{\mathbf{2}}\right.$

$$
33
$$

$J_{k_{\text {reg(a) }}=1447209}$

$$
33
$$

$\mathrm{Jk}_{\mathrm{reg}(\mathrm{a})}=\mathbf{4 3 8 5 4 , 8 1}$

\section{Langkah Keenam}

Mencari jumlah kuadrad regresi $\left(\mathrm{Jk}_{\text {reg(bla) }}\right)$ dengan rumus: 


$$
\begin{aligned}
& \left(\mathbf{J k}_{\text {reg(bla) }}\right)=\mathbf{b} \cdot\left\{\sum \mathrm{XY}-\frac{(\Sigma \mathrm{X}) \cdot(\Sigma \mathrm{Y})}{\mathbf{n}}\right\} \quad\left(\mathbf{R J K}_{\mathrm{Res}}\right)=\frac{\mathbf{J K}_{\text {Res }}}{\mathbf{n - 2}} \\
& \left(J_{\text {reg(b|a) }}\right)=0,28 . \quad\left\{131749-\quad\left(\text { RJK }_{\text {Res }}\right)=\frac{123,75}{33-2}\right. \\
& \left.\frac{(3586) \cdot(1203)}{33}\right\} \quad\left(\text { RJK Kes }_{\text {Res }}\right) \frac{=123,75}{31} \\
& \left(\mathrm{Jk}_{\mathrm{reg}(\mathrm{b} \mid \mathrm{a})}\right)=0,28 . \quad\{131749- \\
& \left(\text { RJK }_{\text {Res }}\right)=3,99
\end{aligned}
$$$$
\left.\frac{4313958}{33}\right\}
$$

\section{Langkah Kesebelas}

Menguji signifikan dengan rumus:

$$
\begin{aligned}
& \left(\mathrm{Jk}_{\mathrm{reg}(b \mid a)}\right)=0,28 . \quad\{131749- \\
& 130726\}
\end{aligned}=
$$

$$
F_{\text {hitung }}=\frac{\text { RJKReg(bla) }_{\text {RJKes }}}{\text { RJK }_{\text {Res }}}
$$$$
F_{\text {hitung }}=\underline{\mathbf{2 8 6}, 44}
$$$$
\left(J_{\text {reg(bla })}\right)=0,28 . \quad\{131749-
$$

$\left(\mathrm{Jk}_{\mathrm{reg}(\mathrm{b} \mid \mathrm{a})}\right)=\mathbf{0 , 2 8} .1023$

$\left(\mathrm{Jk}_{\mathrm{reg}(\mathrm{bla})}\right)=\mathbf{2 8 6 , 4 4}$

\section{Langkah Ketujuh}

Mencari jumlah kuadrad residu ( $\left.\mathrm{JK}_{\mathrm{Res}}\right)$ dengan rumus:

$$
\begin{aligned}
& J_{K_{R e s}}=\sum Y^{2}-J_{\text {reg(bla)- }} \mathbf{J K}_{\text {reg(a) }} \\
& J_{\text {Res }}=\mathbf{4 4 2 6 5}-\mathbf{2 8 6 , 4 4}-\mathbf{4 3 8 5 4 , 8 1} \\
& J_{K_{\text {Res }}}=\mathbf{1 2 3 , 7 5} \\
& \text { Langkah Kedelapan }
\end{aligned}
$$

\section{Langkah Kedelapan}

Mencari rata-rata jumlah kuadrat regresi $\left(\mathrm{RJK}_{\mathrm{Reg}(\mathrm{a})}\right)$ dengan rumus:

$$
\begin{aligned}
& \operatorname{RJK}_{\operatorname{Reg}(a)}=J_{K_{\operatorname{Reg}(a)}} \\
& \operatorname{RJK}_{\operatorname{Reg}(a)}=\mathbf{4 3 8 5 4 , 8 1}
\end{aligned}
$$

\section{Langkah kesembilan}

Mencari rata-rata jumlah kuadrat regresi (RJK $\left.\mathrm{Reg}_{\mathrm{b}(\mathbf{b} \mathbf{a})}\right)$ dengan rumus:

$$
\begin{aligned}
& \left(\operatorname{RJK}_{\operatorname{Reg}(b \mid a)}\right)=J_{K_{\operatorname{Reg}(b \mid a)}} \\
& \left(\operatorname{RJK}_{\operatorname{Reg}(b \mid a)}\right)=\mathbf{2 8 6 , 4 4}
\end{aligned}
$$

\section{Langkah Kesepuluh}

Mencari rata-rata jumlah kuadrat residu (RJKRes)dengan rumus:

$$
3,99
$$$$
F_{\text {hitung }}=\mathbf{7 1 , 7 8}
$$

Kaidah pengujian signifikansi:

Jika $F_{\text {hitung }} \geq F_{\text {tabel, }}$ maka tolak $\mathrm{H}_{0}$ artinya signifikan, dan Jika $F_{\text {hitung }} \leq F_{\text {tabel, }}$ maka terima $\mathrm{H}_{0}$ artinya tidak signifikan.

Dengan taraf signifikan $(\propto)=0,05$. Untuk mencari nilai $F_{\text {tabel }}$ menggunakan tabel $\mathrm{F}$ dengan rumus:

$$
\begin{aligned}
& \mathrm{F}_{\text {tabel }}=\mathrm{F}(1-\propto)(\mathrm{dkReg}(\mathrm{b} \mid \mathrm{a}) .(\mathrm{dkRes}) \\
& \mathrm{F}_{\text {tabel }}=\mathrm{F} \quad(1-0,05) \quad(\mathrm{dkReg}(\mathrm{bla})=33 . \\
& (\mathrm{dkRes})=33-2=31 \\
& \mathrm{~F}_{\text {tabel }}=\mathrm{F}(0,95)(1,31) \\
& \mathrm{F}_{\text {tabel }}=4,17
\end{aligned}
$$

Ternyata $F_{\text {hitung }} \geq \mathrm{F}_{\text {tabel }}$, maka ditolak $\mathrm{H}_{0}$, artinya signifikan.

\section{Langkah Keduabelas}

Membuat kesimpulan

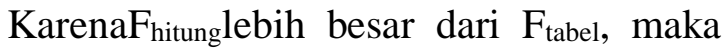
ditolak $\mathrm{H}_{0}$ dan diterima $\mathrm{H}_{\mathrm{a}}$. Dengan demikian terdapat pengaruh yang positif atau signifikan antara pengetahuan pendidikan karakter dengan etika siswa di Madrasah Ibtidaiyah Nurul Huda Parit \% Sungai Luar Kecamatan Batang Tuaka. 
Berdasarkan pembahasan data melalui angket dapat dilakukan analisa sebagai berikut:

1. Melalui analisa data pada variabel $X$, yaitu pengetahuan pendidikan karakter di Madrasah Ibtidaiyah Nurul Huda Parit 5 Sungai Luar kecamatan Batang Tuaka, mencapai angka 60,37\% dan dikategorikan cukup baik, karena angka terletak pada interval $41 \%$ $60 \%$.

2. Melalui analisa data pada variabel Y, yaitu etiket siswa di Madrasah Ibtidaiyah Nurul Huda Parit 5 Sungai Luar kecamatan Batang Tuaka, mencapai angka $60,75 \%$ dan dikategorikan cukup baik, karena angka terletak pada interval $41 \%$ $60 \%$.

3. Melalui analisa data terhadap kedua variabel di atas didapat hasil $\mathrm{F}_{\text {hitung }} \geq$ $\mathrm{F}_{\text {tabel }}$ maka ditolak $\mathrm{H}_{0}$ dan diterima $\mathrm{H}_{\mathrm{a}}$. Dengan demikian terdapat pengaruh yang positif atau signifikan antara pengetahuan pendidikan karakter dengan etika siswa di Madrasah Ibtidaiyah Nurul Huda Parit 5 Sungai Luar Kecamatan Batang Tuaka.

\section{KESIMPULAN}

Berdasarkan dari hasil penelitian yang penulis lakukan melalui angket maka penulis menemukan bahwa pengetahuan pendidikan karakter di Madrasah Ibtidaiyah Nurul Huda Parit 5 Sungai Luar kecamatan Batang Tuaka dengan kategori "cukup baik" dan persentase akhir 60,37\%. Etiket siswa di Madrasah Ibtidaiyah Nurul Huda Parit 5 Sungai Luar kecamatan Batang Tuaka dengan kategori "cukup baik" dan persentase akhir $\mathbf{6 0 , 7 5 \%}$.
Pengetahuan pendidikan karakter dengan etika siswa di Madrasah Ibtidaiyah Nurul Huda Parit 5 Sungai Luar Kecamatan Batang Tuaka terdapat pengaruh positif atau signifikan .

\section{REFERENSI}

Abdullah dan Safarina. 2016. Etika Pendidikan Keluarga sekolah dan Masyarakat. Jakarta: PT. Raja Grafindo Persada.

Alfian.1980. Politik, Kekulturan dan Manusia Indonesia. Jakarta: LP3S.

Al-Qur'an Terjemah Surat At Tin Ayat 4 dan 5

Alya, Onita. 2011. Kamus Bahasa Indonesia. Jakarta: PT. Indah Jaya Adi Pratama.

Arikunto, Suharsimi. 2010. Prosedur Penelitian Suatu Pendekatam Praktik. Jakarta: PT Rineka Cipta.

Bagus, Lorens. 2000. Kamus Filsafat. Jakarta: Gramedia.

Barnawi, M. Arifin. 2016. Strategi dan Kebijakan Pembelajaran Pendidikan Karakter. Yogyakarta: Ar-Ruzz Media.

Gunawan, Heri. 2014. Pendidikan Karakter Konsep dan Implementasi. Bandung: ALFABETA.

Hadi El-Sutha, Saiful. 2015. Pintar Mendidik Anak Ala Rasulullah (Tuntunan Mendapatkan Anak Shaleh/Shalehah Dari Fase Pra Hamil Hingga Usia Remaja). Jakarta: Radar Jaya Offset.

Hajar Al-Asqalani, Ibnu. 2006. Ringkasan Targhib wa Tarhib. (Jakarta: Pustaka Azzam.

Hermino, Agustinus. 2014. Manajemen Kurikulum Berbasis Karakter. Bandung: Alfabeta.

Hidayatullah, M. Furqon. 2010. Pendidikan Karakter: Membangun Peradaban Bangsa. Surakarta: Yuma Pustaka 
Istijianto M.M. 2005. Aplikasi Praktis Riset Pemasaran. Jakarta: PT Gramedia Pustaka Utama.

Kamus Besar Bahasa Indonesia. 2008. Jakarta: Gramedia Pustaka Utama.

Kementerian Agama RI. 2012. Al-Qur'an Dan Terjemahnya. Bandung: Cordoba Internasional Indonesia.

Kesuma, Dharma, Cepi Triana, dan Johar Permana. 2012. Pendidikan Karakter. Bandung: PT Remaja Rosdakarya.

Khan, D. Yahya. 2010. Pendidikan Karakter Berbasis Potensi Diri. Yogyakarta: Pelangi Publishing.

Kuncoro, Mudrajad.2007. Metode Kuantitatif: Teori dan Aplikasi untuk Bisnis dan Ekonomi. Yogyakarta: Unit Penerbit dan Percetakan (UPP) STIM YKPN.

Mahbubi, M. 2012. Pendidikan Karakter: Implementasi Aswaja sebagai Nilai Pendidikan Karakter. Yogyakarta: Pustaka Ilmu Yogyakarta.

Majid, Abdul dan Dian Andayani. 2011. Pendidikan Karakter Perspektif Islam. Bandung: PT Remaja Rosdakarya.

Materi Ajar Mata Kuliah Pendidikan Pancasil Direktorat Pembelajaran Dan Kemahasiswaan Direktorat Jenderal Pendidikan Tinggi Departemen Pendidikan Nasional Kementerian Pendidikan Dan Kebudayaan Republik Indonesia.

Megawangi, Ratna. 2007. Pendidikan Karakter Solusi yang Tepat untuk Membangun Bangsa. Jakarta: Indonesia heritage Foundation.

Naim, Ngainun. 2012. Character Building: Optimalisasi Peran Pendidikan dalam Pengembangan Ilmu \& Pembentukkan Karakter Bangsa. Jogjakarta: Ar-Ruzz Media

Poerwadarminta. 1997. Kamus Besar Bahasa Indonesia. Jakarta: Balai Pustaka.

Rahmaniyah, Istighfatur. 2010. Pendidikan Etika. Malang: UIN Maliki Press.
Riduwan. 2005. Belajar Mudah Penelitian Untuk Guru, Karyawan dan Peneliti Pemula. Bandung: Alfabeta.

Riduwan. 2015. Dasar-dasar Statistika. Bandung: Alfabeta.

Salahudin, Anas dan Irwan Alkrieniehie. 2013. Pendidikan Karakter; Pendidikan Berbasis Agama dan Budaya Bangsa. Bandung: CV Pustaka Setia.

Samani, Muchlas \& Hariyanto. 2013. Pendidikan Karakter: Konsep dan Model. Bandung: PT Remaja Rosdakarya.

semiawan, Conny dan dkk. 1987. Tata krama Pergaulan. Jakarta: Balai Pustaka.

Shihab, M Quraish. 2016. Yang Hilang Dari Kita Ahlak. Tanggerang: Lentera Hati.

Sugiono. 2016. Metodologi Penelitian Pendidikan. Bandung: Alfabeta.

Suharti. 2004. Pendidikan Sopan Santun Dan Kaitannya Dengan Perilaku Berbahasa Jawa Mahasiswa. Yogyakarta: DIKSI.

Syafaruddin. Tim Editor Bahan Ajar PLPG Pendidikan Agama Islam. Medan: FITK Universitas Islam Negeri Sumatera Utara.

Taniredja, Tukiran, dkk. 2012. Paradigma Baru Pendidikan Pancasila Untuk Mahasiswa. Bandung: ALFABETA.

Undang-undang Sistem Pendidikan Nasional. 2006. Yogyakarta: Pustaka Pelajar.

Wiyadi. 2010. Membina Akidah Akhlak. Solo: PT Tiga Serangkai.

Zaenul Fitri, Agus. 2012. Reinventing Human Character: Pendidikan Karakter Berbasis Nilai \& Etika di Sekolah. Jogjakarta: Ar-Ruzz Media.

Zuriah. 2008. Pendidikan Moral Dan Budi Pekerti Dalam Perspektif Perubahan. Jakarta: Bumi Aksara. 